\title{
Investigation on extracellular lipase production by Aspergillus japonicus isolated from the paper nest of Ropalidia marginata
}

\author{
A. Jayaprakash and P. Ebenezer \\ Centre for Advanced Studies in Botany, University of Madras, Guindy Campus, Chennai 600 025, Tamil Nadu, India. \\ aruljaypee@gmail.com
}

\begin{abstract}
Aspergillus japonicus isolated from the paper nest of Ropalidia marginata was screened for its extracellular lipase production. Maximum lipase activity $(120 \mathrm{U} / \mathrm{ml})$ was achieved by manipulating the culture environment. The optimum $\mathrm{pH}$ was 7.5 and the temperature was $40^{\circ} \mathrm{C}$. Sucrose served as the best carbon source whereas peptone was the best nitrogen source for lipase production. An animal fat, pig fat in the culture medium enhanced lipase production. These investigations will be helpful in further scaling-up processes of this industrial enzyme. Owing to many applications in high-value syntheses and as bulk enzymes, lipases have high impact on bioprocessing.
\end{abstract}

Keywords: Aspergillus japonicus; paper nest; pig fat; Ropalidia marginata; lipase; Tween-20.

Introduction

Lipases (Triacylglycerol acyl hydrolase E.C.3.1.1.3) are lipolytic serine esterases that are secreted by many fungi, yeasts and bacteria. Lipases are active at their interface between their hydrophobic lipid substrate and the hydrophilic space medium (oil-water interface) cleaving water-insoluble glycerides into molecules that can be readily imbibed by cells (Jaegar \& Eggert, 2002). Microbial lipases have assumed a great deal of importance as industrial enzymes in view of their potential for use in various biotechnological processes. Fungi are important enzyme producers since they produce enzymes extracellularly (Ferreira \& Peralta, 1999). Lipases are being exploited due to their low cost of extraction, thermal and $\mathrm{pH}$ stability, substrate specificity, and activity in organic solvents. Lipases are the most widely used enzymes in organic synthesis and more than $20 \%$ biotransformations are performed with lipases (Gitlesen et al., 1997). Besides their role in synthetic organic chemistry, these enzymes also find extensive applications in chemical, pharmaceutical, food and leather industries (Gulati et al., 2005). Promising areas for the application of lipases include the biodegradation of plastics (Gombert et al., 1999) and the resolution of racemic mixtures to produce optically active compounds (Muralidhar et al., 2001). These attributes of lipases owe to their broad specificity for a wide spectrum of substrates, stability in organic solvents and enantioselectivity (Snellman \& Colwell, 2004).

The production of lipases is influenced by many factors such as $\mathrm{pH}$, temperature, carbon and nitrogen (George et al., 1999). Aspergillus spp. are natural 'factories' for the production of enzymes such as cellulases, xylanases, amylases, proteases, and lipases. Owing to their ability for elaborating an array of extracellular enzymes, aspergilli play an important role in the production of industrial enzymes (Lockington et al.,
2002). The industrial demand for lipolytic enzymes continues to stimulate the search for new enzyme sources. In view of the diversity in applications, renewed interest is evinced in the development of new sources of lipases. Sources of bacteria, yeasts and moulds produce lipases with different enzymological properties and specificities but moulds are known to be more potent lipase producers (Choo et al., 1998). Aspergillus spp. are among the most well known lipase producers and their enzymes are suitable for use in many industrial applications ( $\mathrm{Fu}$ et al., 1995). Although many lipases have already been described, the search for new lipases with greater thermostability and substrate selectivity is on (Mateos et al., 2006).

Fig. 1. Paper nest of Ropalidia marginata

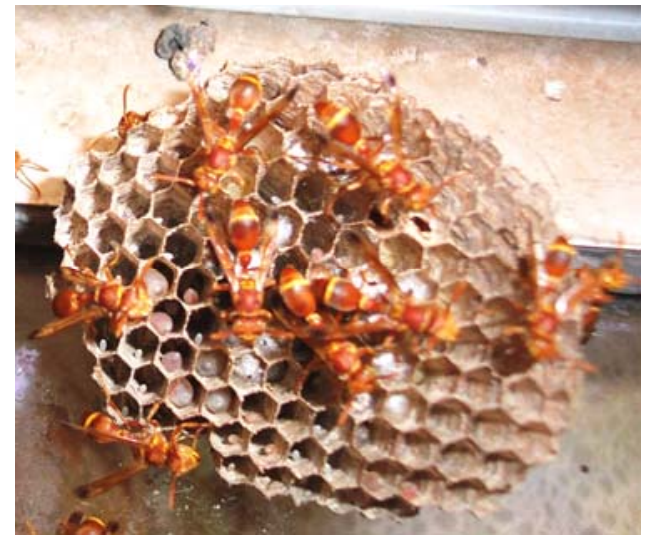

In this study, $A$. japonicus isolated from the paper nest of Ropalidia marginata was investigated for its ability to elaborate lipase enzyme vis-a-vis the culture environment. The enzyme production was optimized against the environmental variables such as culture medium, carbon and nitrogen sources and the influence
Research article

CIndian Society for Education and Environment (iSee)
"Aspergillus japonicus lipase" http://www.indjst.org
Jayaprakash \& Ebenezer Indian J.Sci.Technol. 
of $\mathrm{pH}$ and temperature as also certain lipid inducers. The enzyme was grown in a minimal production medium containing pig fat for enhanced lipase production for further scaling up process.

\section{Materials and methods}

Isolation of $A$. japonicus from the paper nest of Ropalidia marginata

The paper nest of Ropalidia marginata was collected from a glass house at CAS in Botany, University of Madras (Fig. 1). The paper nest was surface sterilized with $0.1 \%$ mercuric chloride for $2 \mathrm{~min}$ and washed thoroughly in sterile distilled water for 2 min and the bits plated on PDA and incubated at $25^{\circ} \mathrm{C}$ for a week. A fungus, identified as $A$. japonicus (Deuteromycete: Hyphomycetes), was isolated from the paper nest of $R$. marginata (Fig. 2). After isolation, the fungus was subcultured and the pure culture was stored in PDA at $4^{\circ} \mathrm{C}$.

Fig. 2. Spore morphology of A. japonicus

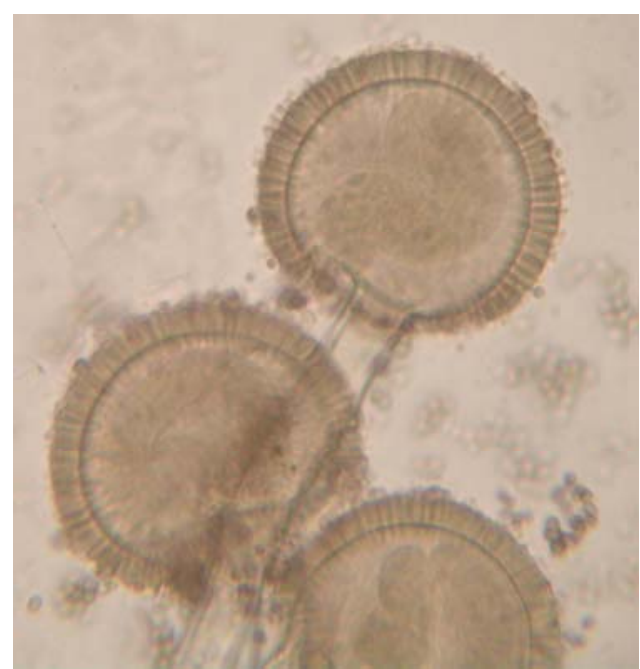

Lipase activity on Rhodamine-B agar plates

The fungal strain was tested for lipase production on agar plates that contained $15 \mathrm{~g}$, olive oil $10 \mathrm{ml}$, Rhodamine-B $0.01 \mathrm{~g}$ and Tween- $800.001 \%$ in $1000 \mathrm{ml}$ of distilled water. After 7 days of incubation at $28^{\circ} \mathrm{C}$, the plate was irradiated with UV light $(350 \mathrm{~nm})$, with a bright pink fluorescent halo confirming lipolytic activity (Valeria et al., 2003).

\section{Lipase production medium}

Modified lipase medium (YEP) was prepared by adding $10 \mathrm{~g}$ peptone and $1 \mathrm{~g}$ yeast extract to $1000 \mathrm{ml}$ of $0.1 \mathrm{M}$ phosphate buffer, pH 7.0 (Roberts et al., 1987). Then, $1 \%$ filter sterilized glucose was added to the sterile peptone-yeast extract solution. Sterile erlenmeyer flasks $(250 \mathrm{ml})$ containing $100 \mathrm{ml}$ sterile yeast-extract-peptone medium with glucose were inoculated with $2 \mathrm{ml}$ spore suspension from 7 day old culture of the test fungi and incubated with incidental illumination at $30^{\circ} \mathrm{C}$ in a rotary shaker at $120 \mathrm{rpm}$. After 5 days of incubation, the cultures were filtered through a filter paper to remove the mycelium. The sterile culture filtrates were stored at $-20^{\circ} \mathrm{C}$ for further use. The culture filtrate was used as the enzyme source.

Fig. 3. Extracellular lipase activity by $A$. japonicus on Rhodamine-B plate irradiated under UV

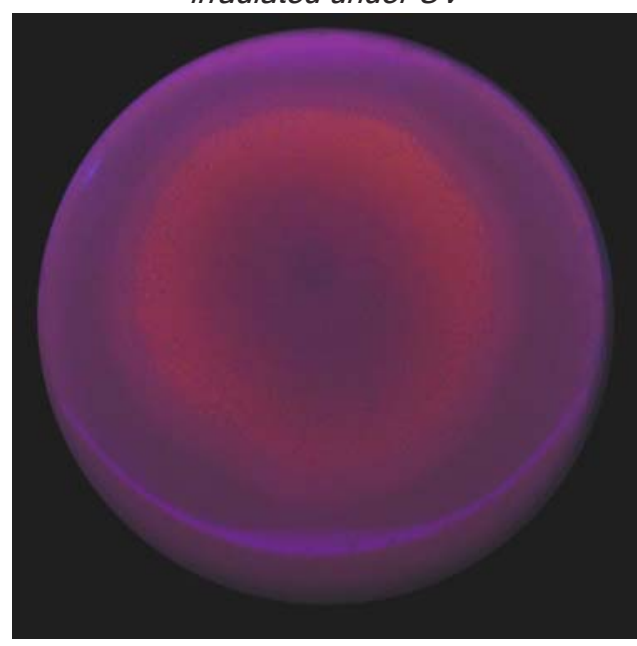

Spectrophotometric assay for lipase activity

Lipase activity was assayed quantitatively by using $\rho$-nitro phenyl palmitate as the substrate (Winkler \& Stuckmann, 1979). $10 \mathrm{ml}$ isopropanol containing $30 \mathrm{mg}$ $\rho$-nitro phenyl palmitate (Sigma) was mixed with $90 \mathrm{ml}$ $0.05 \mathrm{M}$ sodium phosphate buffer $(\mathrm{pH} 8)$ containing $207 \mathrm{mg}$ sodiumdeoxycholate and $100 \mathrm{mg}$ gum arabic. A total volume of $2.4 \mathrm{ml}$ freshly prepared substrate solution was prewarmed at $37^{\circ} \mathrm{C}$ and mixed with $0.1 \mathrm{ml}$ enzyme solution. After $15 \mathrm{~min}$ incubation at $37^{\circ} \mathrm{C}$, absorbance at $410 \mathrm{~nm}$ was measured against a blank. One enzyme unit was defined as $1 \mu \mathrm{mol}$ of $\rho$-nitrophenol enzymatically released from the substrate in milliliters per minute.

\section{Effect of $\mathrm{pH}$}

The effect of $\mathrm{pH}$ was studied by adjusting the YEP medium to different $\mathrm{pH}$ values-5.5 to 9.5. Erlenmeyer flasks $(250 \mathrm{ml})$ containing $100 \mathrm{ml}$ of YEP medium were inoculated with a $7 \mathrm{~mm}$ mycelial disc of 7 day old culture of $A$. japonicus and incubated over a period of 7 days at room temperature. The lipase activity was measured in the culture filtrate after the incubation period.

\section{Effect of temperature}

The effect of temperature was studied by incubating the test fungi at different temperatures. Erlenmeyer flasks $(250 \mathrm{ml})$ containing $100 \mathrm{ml}$ of YEP medium with $\mathrm{pH} 7.5$ were inoculated with a $7 \mathrm{~mm}$ mycelial disc of 7 day old culture of $A$. japonicus and incubated over a period of 7 days at different temperatures $\left(20^{\circ} \mathrm{C}-80^{\circ} \mathrm{C}\right)$. Lipase activity was estimated in the culture filtrate after the incubation period.
Research article

COIndian Society for Education and Environment (iSee)
"Aspergillus japonicus lipase" http://www.indjst.org
Jayaprakash \& Ebenezer Indian J.Sci.Technol. 


\section{Effect of carbon source}

Glucose, sucrose, galactose, lactose, fructose, maltose, ribose, mannitol, starch or glycogen were added to the lipase production medium at $1.0 \%$, inoculated with $7 \mathrm{~mm}$ mycelial discs from 7 day old culture of $A$. japonicus and incubated for a period of 7 days at optimum $\mathrm{pH}$ and temperature. Lipase activity was estimated in the culture filtrate after the incubation period.
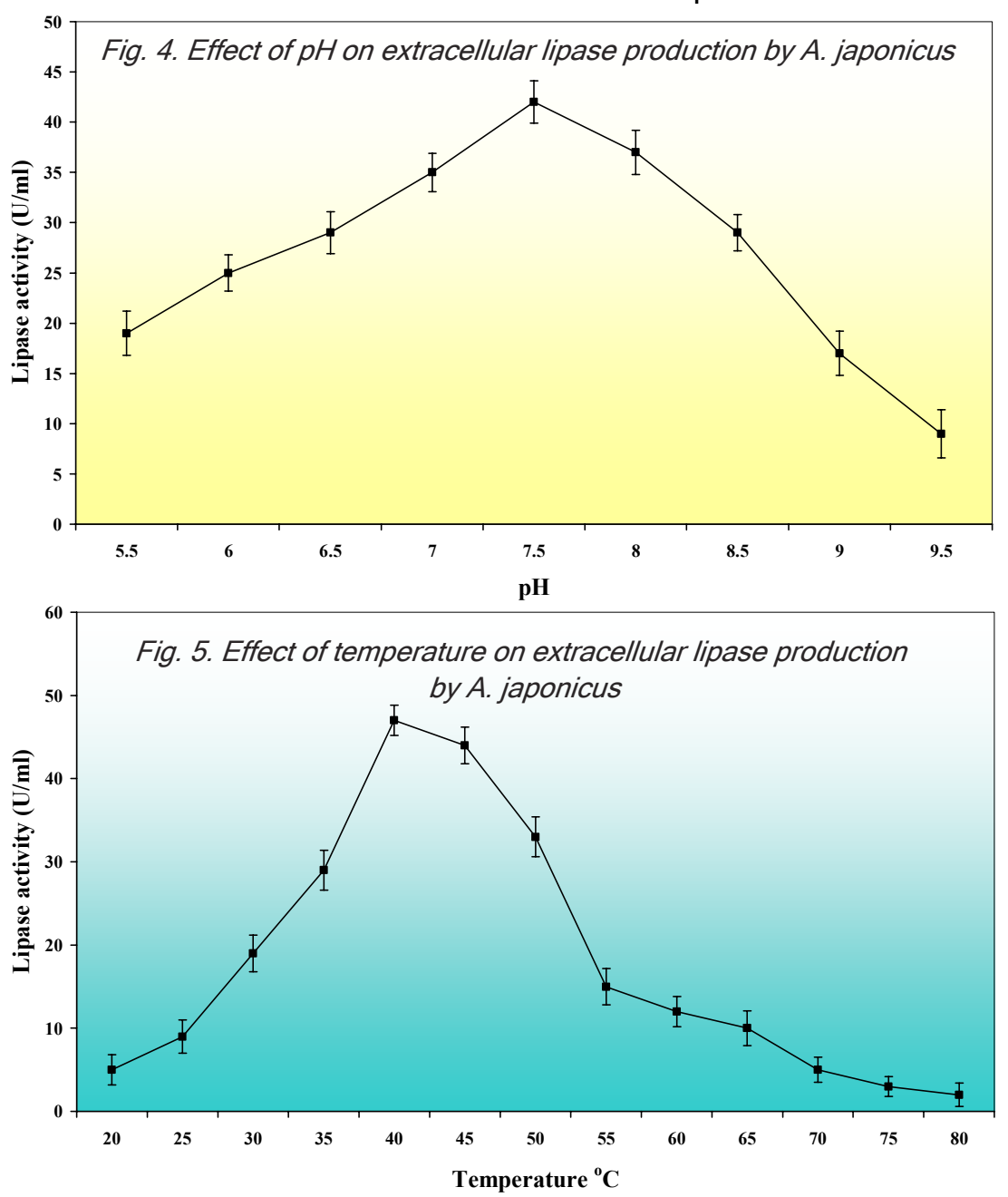
source.

Vol. 3 No. 2 (Feb 2010)

ISSN: 0974- 6846

fat (pig fat) was amended to the lipase production medium at $1.0 \%$ each. Olive oil, sunflower oil, castor oil, mustard oil or groundnut oil were used as vegetable oil source. Aspergillus japonicus was inoculated into the production medium and incubated as above. The culture filtrate after 7 days incubation served as the enzyme

Effect of incubation time and aeration

The lipase production medium inoculated with the test fungus was incubated for a period of 7 days in both shaken and stationary states. The enzyme activity was assayed for every $24 \mathrm{~h}$, in both shaken and stationary culture filtrates and the results were plotted against the biomass of the culture filtrate.

\section{Biomass}

The biomass of the test fungus grown in the lipase production medium was estimated by measuring the dry weight. The mycelium from the liquid culture was harvested and dried in an oven and the dry weight was estimated. The harvested mycelium was dried in a preweighed filter paper by incubating it in an oven at $60^{\circ} \mathrm{C}$ to a constant weight (Prescott et al., 1993). Statistical analysis

All the experiments were carried out in triplicate; the data were analyzed by a twoway ANOVA with an Agres statistical software package (Agres, 1994). The least significant difference (LSD) analysis was performed to group the treatment mean values. The values presented in the graphs are those of the mean of three independent experiments and the error bars indicate standard deviation.

\section{Results and discussion}

The influences of various environmental factors such as $\mathrm{pH}$, temperature, nitrogen, carbon and lipid sources on lipase

\section{Effect of nitrogen source}

Organic nitrogen sources like peptone, soybean meal extract or yeast extract and inorganic nitrogen sources such as ammonium chloride, ammonium sulphate, ammonium nitrate or urea was added to YEP medium at $1.0 \%$, inoculated with $7 \mathrm{~mm}$ mycelial discs from seven day old culture of $A$. japonicus and incubated for a period of 7 days at optimum $\mathrm{pH}$ and temperature. The lipase activity was measured in the culture filtrate after the incubation period.

Effect of inducers

Different lipid sources at $1.0 \%$ were added to the lipase production medium as inducers of lipase. Tween-20, Tween-40, Tween-60, Tween-80, Tween-100, tributyrin or likewise, different vegetable oils or an animal production were well documented. After having screened the fungus isolated from the paper nest which has a waxy coating, for the production of extracellular lipase in the laboratory, the necessary confirmation test for the enzyme was carried out. Subsequently, the enzyme production was quantified by a suitable spectrophotometric method by manipulating the culture environment. Extracellular lipase activity on Rhodamine-B agar was witnessed as a bright pinkish red fluorescent zone around the colonies indicating that the enzymes produced are but lipases (Valeria et al., 2003). The enzyme is believed to interact with the dye, Rhodamine-B leading to a complex- formation which fluoresces when exposed to ultraviolet radiation (Fig. 3).
"Aspergillus japonicus lipase" http://www.indjst.org
Jayaprakash \& Ebenezer Indian J.Sci.Technol. 
The culture environment has a dramatic influence on enzyme production (Elibol \& Ozer, 2001). Enzyme yields can be enhanced several fold by providing the suitable cultural conditions both physical and chemical. The initial $\mathrm{pH}$ of the culture medium is crucial for enzyme production. A near neutral $\mathrm{pH}$ (7.5) was found to have favoured lipase secretion in $A$. japonicus (Fig. 4). In contrast, Jonsson and Snygg (1974) observed elevated growth and lipase production in Mucor caseolyticus at an acidic $\mathrm{pH}$ (4.0). Temperature as one of the important factors of the physical environment also profoundly influences enzyme secretion (Oso, 1978). Aspergillus japonicus lipase was most active at $40^{\circ} \mathrm{C}$, pointing to its thermotolerance (Fig. 5). This attribute is advantageous for application in industries as most industrial processes

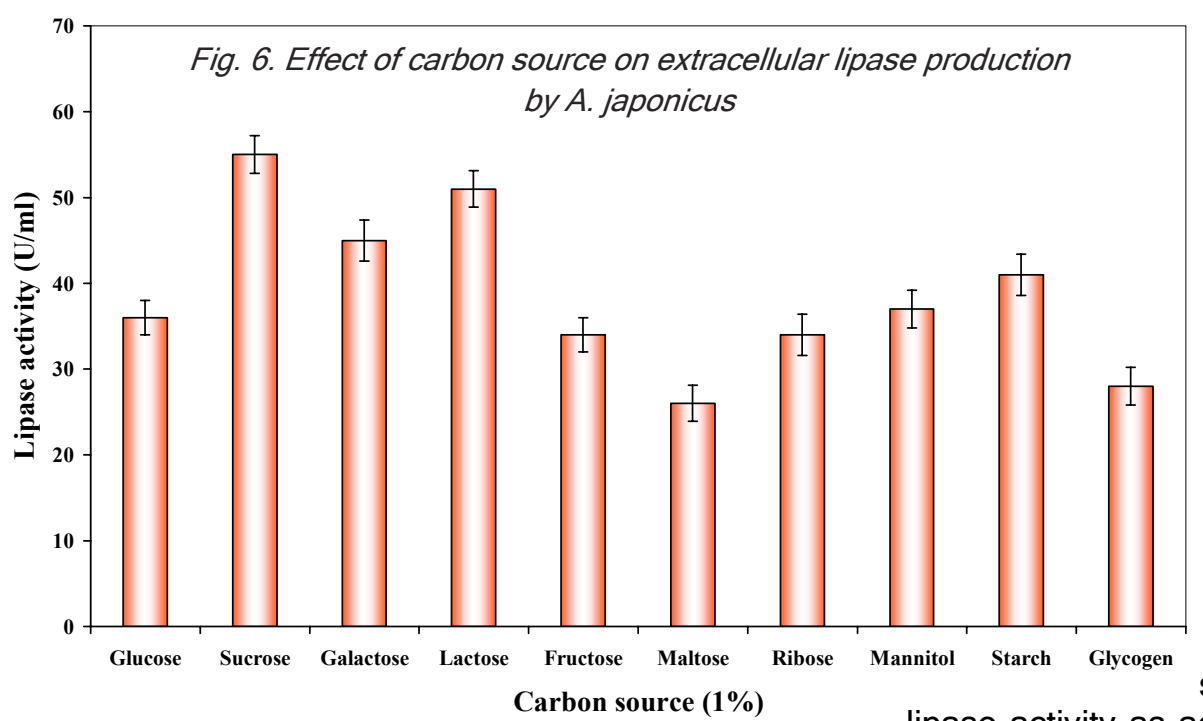

Maia et al., 2001). Carbon and nitrogen sources play a crucial role in enzyme induction in microorganisms.

Sucrose favoured maximum lipase activity in $A$. japonicus while, an organic nitrogen peptone exerted the same effect (Fig. $6 \& 7$ ). As for lipid substrates as inducers, although triglycerides are well known for their positive effects on lipase induction in microorganism, in this study pig fat favoured maximum activity of the enzyme (Fig. 8). Similar trend was observed by Yadav et al. (1998). The production medium with $\mathrm{pH} 7.5$ was inoculated with $A$. japonicus with sucrose, peptone and pig fat at $1.0 \%$ each at $40^{\circ} \mathrm{C}$ over a period of 7 days in both shaken and stationary states to study the effect of aeration. The enzyme activity was estimated at $24 \mathrm{~h}$ intervals in both shaken and stationary culture filtrates. The biomass and the concomitant enzyme activity were maximum on the $7^{\text {th }}$ day. The biomass was $1.08 \mathrm{~g} \mathrm{ml}^{-100}$ in stationary cultures while the same was $1.23 \mathrm{~g} \mathrm{ml}^{-100}$ in shaken cultures. The lipase activity was also maximum on the $7^{\text {th }}$ day. Lipase activity was $105 \mathrm{U} / \mathrm{ml}$ in stationary cultures whereas it was $120 \mathrm{U} / \mathrm{ml}$ in shaken cultures. There was a gradual decrease in lipase activity from $8^{\text {th }}$ day onwards of incubation and no change in biomass was observed either (Table 1).

Aeration also exerts its own influence on enzyme synthetic processes in microbes. In this study, shaken cultures yielded maximum lipase activity as against static culture. Incubation period also is crucial for enzyme elaboration. A 7 day incubation offered good yield of the enzyme in the test organism.

Therefore, these environmental factors need a careful and judicious management so as to reap a good harvest

take place at elevated temperatures. Fusarium solan FS1, F. oxysporum f. sp. vasinfectum are known to elaborate thermotolerant lipases (Hoshino et al., 1991;

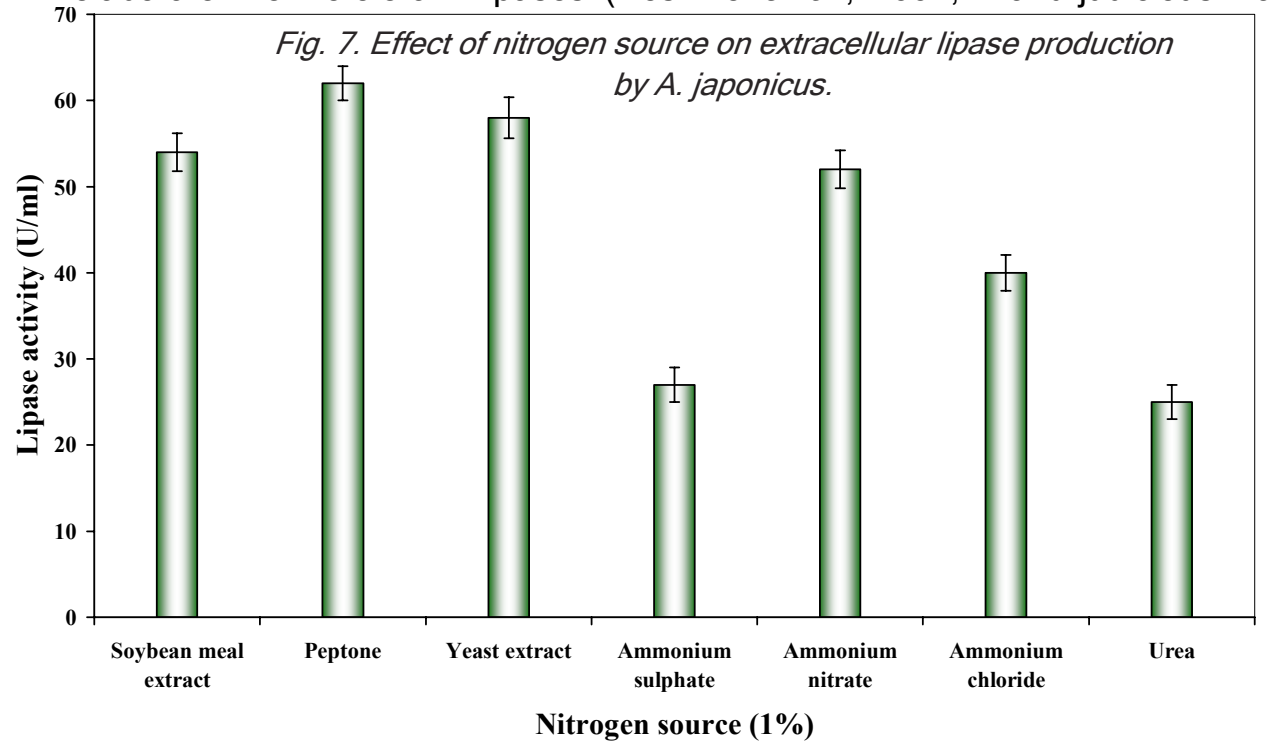

Research article

CCIndian Society for Education and Environment (iSee)
"Aspergillus japonicus lipase" http://www.indjst.org of this industrial enzyme. This investigation reveals that the environment greatly influences enzyme production and that its optimization needs a careful manipulation of the cultural environment. The indication that the enzyme showed a tendency towards thermotolerance merits further consideration for developing the same towards this goal for better industrial application.

\section{Acknowledgements}

The authors thank Prof. $R$. Rengasamy, Director, Centre for Advanced Studies in Botany, University of Madras for providing necessary laboratory facilities. 
Table 1. Relationship between biomass and lipase secretion in $A$. japonicus

\begin{tabular}{|c|c|c|c|c|}
\hline $\begin{array}{c}\text { Incubation } \\
\text { period } \\
(\mathrm{hrs})\end{array}$ & \multicolumn{2}{|c|}{$\begin{array}{c}\text { Biomass } \\
\left(\mathrm{g} / \mathrm{m}^{-100}\right)\end{array}$} & \multicolumn{2}{c|}{$\begin{array}{c}\text { Lipase activity } \\
(\mathrm{U} / \mathrm{ml})\end{array}$} \\
\cline { 2 - 5 } & Stationary & Shaken & Stationary & Shaken \\
\hline 24 & $0.98 \pm 0.02^{\mathrm{k}}$ & $1.10 \pm 0.02^{\mathrm{fg}}$ & $87 \pm 1.7^{\mathrm{n}}$ & $92 \pm 1.8^{\mathrm{l}}$ \\
\hline 48 & $1.01 \pm 0.02^{\mathrm{ij}}$ & $1.13 \pm 0.02^{\mathrm{e}}$ & $91 \pm 1.8^{\mathrm{m}}$ & $101 \pm 2.0^{\mathrm{h}}$ \\
\hline 72 & $1.00 \pm 0.02^{\mathrm{j}}$ & $1.15 \pm 0.02^{\mathrm{d}}$ & $93 \pm 1.8^{\mathrm{k}}$ & $107 \pm 2.1^{\mathrm{e}}$ \\
\hline 96 & $1.02 \pm 0.02^{1}$ & $1.16 \pm 0.02^{\mathrm{d}}$ & $97 \pm 1.9^{\mathrm{j}}$ & $107 \pm 2.2^{\mathrm{b}}$ \\
\hline 120 & $1.04 \pm 0.02^{\mathrm{h}}$ & $1.18 \pm 0.02^{\mathrm{c}}$ & $100 \pm 2.0^{\mathrm{1}}$ & $110 \pm 2.1^{\mathrm{e}}$ \\
\hline 144 & $1.06 \pm 0.02^{\mathrm{g}}$ & $1.21 \pm 0.02^{\mathrm{b}}$ & $103 \pm 2.0^{\mathrm{g}}$ & $115 \pm 2.2^{\mathrm{d}}$ \\
\hline 168 & $1.08 \pm 0.02^{\dagger}$ & $1.23 \pm 0.02^{\mathrm{a}}$ & $105 \pm 2.1^{\dagger}$ & $120 \pm 2.2^{\mathrm{a}}$ \\
\hline 192 & $1.08 \pm 0.02^{\mathrm{g}}$ & $1.23 \pm 0.02^{\mathrm{b}}$ & $103 \pm 2.0^{\mathrm{g}}$ & $118 \pm 2.2^{\mathrm{c}}$ \\
\hline
\end{tabular}

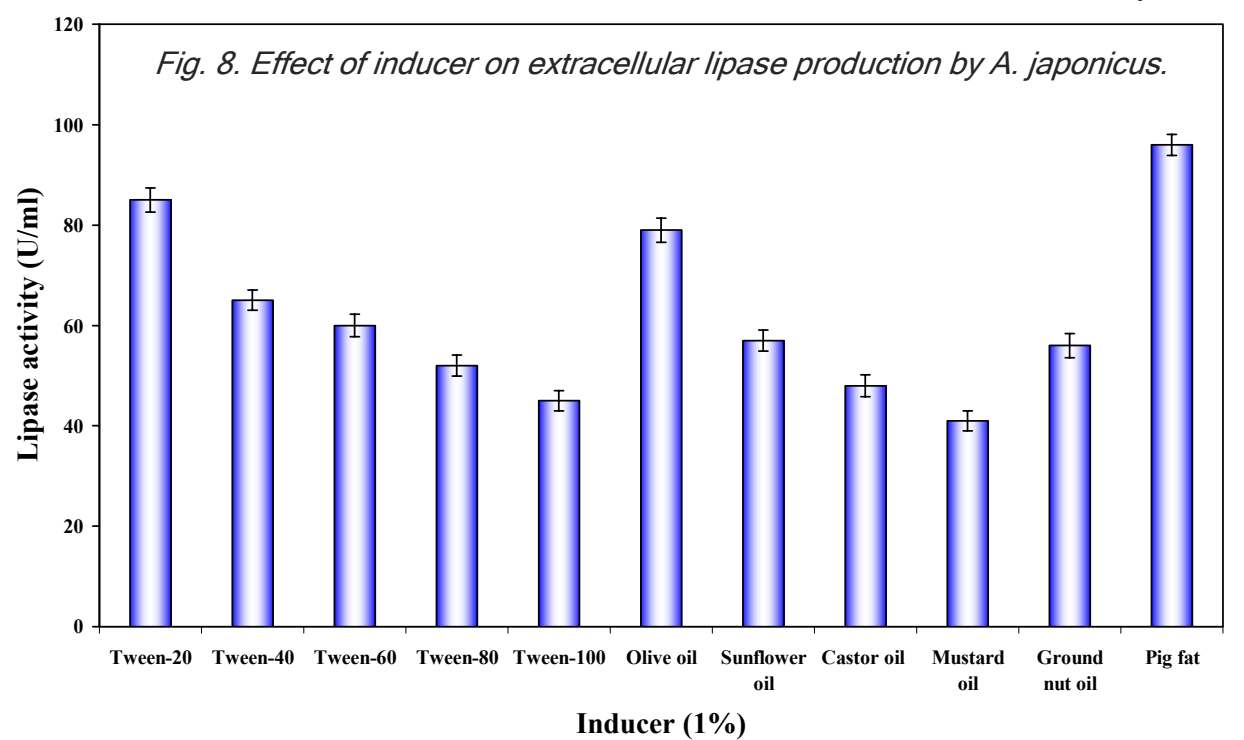

\section{References}

1. Agres (1994) Statistical software version 3.01. Pascal International solutions, USA.

2. Choo DW, kurihara T, Suzuki T, Soda $K$ and Esaki NA (1998) Cold adapted lipase of an Alaskan psychrotroph, Pseudomonas sp., Strain B 11-1: Gene cloning and enzyme purification and characterization. Appl. Environ. Microbiol. 64, 486-491.

3. Elibol M and Ozer D (2001) Influence of oxygen transfer on lipase production by Rhizopus arrhizus. Proc. Biochem. 36, 325-329.

4. Ferreira-Costa MA and Peralta RM (1999) Production of lipase by soil fungi and partial characterization lipase from a selected strain (Penicillium wortmanii). J. Basic. Microbiol. 39, 11-15.

5. Fu X, Zhu X, Gao K and Duan J (1995) Oil and fat hydrolysis with lipase from Aspergillus sp. J. American Oil Chem. Soc. 72, 527-531.

6. George E, Tamerler C, Martinez A, Martinez MJ and Keshavarz T (1999) Influence of growth composition on the lipolytic enzyme activity of Ophiostoma piliferm. J. Chem. Technol. Biotech. 74, 137-140.

7. Gitlesen T, Bauer M and Adlercreutz P (1997) Adsorption of Lipase on polypropylene powder. Biochem. Biophys. Acta. 1345, 188-196.
8. Gombert AK, Pintoal-Castilho LR and Freirc DMG (1999) Lipase by Penicillium restrictum in solid state fermentation using Babassu oil cake as substrate. Proc. Biochem. 35, 85-90.

9. Gulati R, Jasmine ISAR, Vineet K, Parsad A, Parmar V and Saxena K (2005) Production of a novel alkaline lipase by Fusarium globulosum using Neem oil, and its applications. Pure Appl. Chem. 77, 251-262.

10. Hoshino T, Mizutani A, Shimizu S, Hidaka $\mathrm{H}$ and Yamane $\mathrm{T}$ (1991) Calcium ion regulates the release of lipase of Fusarium oxysporum. J. Biochem. 110, 457-461.

11. Jaeger KE and Reetz MT (1998) Microbial lipases form versatile tools for biotechnology. Trend Biotechnol. 16, 396403.

12. Jonsson U and Snygg BG (1974) Lipase production and activity as a function of incubation time, $\mathrm{pH}$ and temperature of four lipolytic microorganisms. J. Appl. Bacteriol. 37(4), 571-581.

13. Lockington R, Rodbourn L, Barnett $S$, Carter C and Kelly J (2002) Regulation by carbon and nitrogen sources of a family of cellulases in Aspergillus nidulans. Fungi Genetics Biol. 37, 190196.

14. Maia MMD, Heasley A, CamargodeMorais MM, Melo $\mathrm{EH}$, Morais MA, Jr. Ledingham WM and Lima FJL (2001) Effect of culture conditions on lipase production by Fusarium solani in batch fermentation. Biores. Technol. 76, 23-27.

15. Mateos DJC, Rodrguez JA, Roussos S, Cordova J, Abousalham A, Carriere $\mathrm{F}$ and Baratti J (2006) Lipase from the thermotolerant fungus Rhizopus homothallicus is more thermostable when produced using solid state fermentation than liquid fermentation procedures. Enz. Microbial. Technol. 39, 1042-1050.

16. Muralidhar RV, Marchant R and Nigam P (2001) Lipases in racemic resolutions. J. Chem. Technol. Biotechnol. 76, 3-8.

17. Prescott LM, Harley JP and Klein DA (1993) Microbiology, Second edn. Wm. C. Brown Publishers, p. 912.

18. Roberts RG, Morrison WH and Robertson JA (1987) Extracellular lipase production by fungi from sunflower seed. Mycologia. 79, 265-273.

19. Snellman EA and Colwell RR (2004) Acinetobacter lipase: molecular biology, biochemical properties and biotechnological potential. J. Industrial Microbiol. Biotechnol. 31, 391-400.

20. Valeria MG, Lima-Nadia K, Maria-Inez M, Sarquis-David A, Mitchell-Luiz P and Ramos-Jose D (2003) Production of Lipase by Penicillium aurantiogriseum. Food Technol. Biotechnol. 41, 105-110.

21. Winkler VK and Stuckmann M (1979) Glycogen, hyaluronate and some other polysaccharides greatly enhance the formation of exolipase by Serratia marcescens. J. Bacteriol. 138, 663-670.

22. Yadav RP, Saxena RK, Gupta R and Davidson WS (1998) Lipase production by Aspergillus and Penicillium spp. Folia Microbiol. 43(4), 373-378.
Research article

COIndian Society for Education and Environment (iSee)
"Aspergillus japonicus lipase" http://www.indjst.org
Jayaprakash \& Ebenezer Indian J.Sci.Technol. 